\title{
„Dziadkowie - rodzice” widziani oczami dorosłych wnuków
}

\begin{abstract}
Abstrakt
Zmiany zachodzące w ostatnich latach w rodzinie coraz częściej przyczyniają się do przejmowania przez dziadków ról związanych z opieką nad wnukami. Dlatego też ważne staje się poszukiwanie odpowiedzi na pytanie dotyczące czynników warunkujących charakter relacji pomiędzy wnukami a „dziadkami-rodzicami”. Celem niniejszego artykułu jest przedstawienie wyników badań ukazujących relacje pomiędzy wnukami a „dziadkami-rodzicami” oraz rolę, jaką najstarsi członkowie rodziny odegrali, zdaniem wnuków, w ich życiu.
\end{abstract}

Słowa kluczowe: dziadkowie, wnuki, wychowanie.

\section{"Grandparents as Parents" Seen Through the Eyes of Adult Grandchildren}

\begin{abstract}
Changes in the family in recent years have contributed more and more frequently to grandparents taking over roles related to caring for grandchildren. Therefore, it becomes important to look for an answer to the question about factors determining the nature of the relationship between grandchildren and grandparents - parents. The purpose of this paper is to present research results showing the relationship between grandchildren and grandparents - parents and the role that the eldest family members played, in the opinion of grandchildren, in their lives.
\end{abstract}

Keywords: grandparents, grandchildren, education.

\footnotetext{
* Uniwersytet w Białymstoku.
} 


\section{Wprowadzenie}

Celem niniejszego artykułu jest przedstawienie wyników badań ukazujących relację pomiędzy wnukami a „dziadkami-rodzicami” oraz rolę, jaką najstarsi członkowie rodziny odegrali w ich życiu.

Zagadnienie dotyczące relacji międzypokoleniowych pomiędzy dziadkami i wnukami opisywane jest przez badaczy reprezentujących różne dyscypliny naukowe. Dzieje się tak dlatego, że w ostatnich dekadach w rodzinie zaszło wiele zmian dotyczących jej struktury i funkcjonowania. Współczesne rodziny stają się coraz bardziej zróżnicowane ze względu na zwiększenie aktywności zawodowej kobiet, późniejsze zawieranie związków małżeńskich, rosnący wskaźnik rozwodów, coraz większą liczbę dzieci żyjących w gospodarstwach domowych z jednym rodzicem, a także ze względu na wydłużającą się średnią długość życia. Ten ostatni czynnik prowadzi do coraz częstszego współistnienia kilku generacji. Oznacza to, że coraz częściej młodzi ludzie mimo upływu lat mają jednego lub więcej dziadków, a są też sytuacje, w których mają możliwość poznania własnych pradziadków. Jak zauważył Anthony Giddens (2012), w związku z faktem, że dziadkowie współcześnie pozostają w niewspółmiernie dłuższym kontakcie z pokoleniem ludzi młodych aniżeli miało to miejsce w przeszłości, jeszcze większego znaczenia nabiera ich rola w życiu wnuków. Natomiast Elżbieta Dubas podkreśla, że dziadkowie mogą

wspierać rodzinę poprzez zaangażowanie w rozwiązywanie rozlicznych, trudnych problemów życia codziennego, (...) zwiększyć swój aktywny udział w czasie wolnym rodziny, (...) intensywniej włączyć się w proces przekazywania wiedzy i wartości, przydatnych w życiu młodszych pokoleń (Dubas 2009: 125).

Należy podkreślić, że we współczesnym świecie dziadkowie nadal kojarzeni są $\mathrm{z}$ „rolą peryferyjną" polegającą na niesieniu pomocy rodzicom bez przejmowania odpowiedzialności za faktyczne wychowanie dzieci (Cox 2000). Z badań prowadzonych w Polsce i na świecie wynika, że dziadkowie są niezastąpionym źródłem pomocy w kontekście sytuacji trudnych, pojawiających się w rodzinie, tj. odejście lub śmierć jednego z rodziców czy samotne rodzicielstwo (Arpino, Pronzato, Tavares 2012; Napora, Kozerska, Schneider 2014).

Jednak coraz częściej dziadkowie przechodzą z tradycyjnych wyobrażeń o swoim miejscu w życiu rodzinnym do ról związanych z przejmowaniem całkowitej opieki nad wnukami (Fitzpatrick 2004; Ochiltree 2006). Ma to miejsce w przypadkach, w których ze względu na sytuację rodzinną dzieci nie są w stanie bezpiecznie pozostać przy rodzicach biologicznych. Zjawisko przejmowania opieki nad wnukami przez dziadków staje się coraz bardziej powszechne na całym świecie. W 2012 r. prawie 40 tysięcy dzieci i młodzieży w Australii zostało objętych formalną opieką krewnych - głównie dziadków (AIHW 2013), w Wielkiej Brytanii ok. 200 tysięcy dziadków wychowuje wnuki (Dziadkowie Plus 2006), a 2,7 miliona 
w USA (Simmons, Dye 2003). Kolejną grupę stanowią dziadkowie, których najlepiej opisać jako „nieformalnych” opiekunów, którzy wychowują wnuki na podstawie rodzinnych ustaleń (Selwyn, Nandy 2012). Przyczyny przejęcia przez dziadków opieki nad wnukami dotyczą zaniedbania, znęcania się nad dziećmi, przemocy w rodzinie, braku chęci lub możliwości w zakresie odpowiedniej opieki nad dziećmi, które mogą wynikać z chorób psychicznych, nadużywania alkoholu lub narkotyków, konfliktów z prawem, śmierci biologicznych rodziców, niewydolności wychowawczej, życiowej bezradności, wzrostu liczby niepełnych rodzin, bezrobocia i ubóstwa, a także migracji (Boetto 2010; Mason i in. 2002; Borowik 2016). W sytuacji gdy dziadkowie przejmują pełną odpowiedzialność za wychowanie wnuków, w życiu najmłodszego pokolenia zachodzą zmiany mające wpływ na ich dalsze życie. Jednak ocena własnego życia przez wnuki z perspektywy relacji z „dziadkami-rodzicami”, którzy przejęli opiekę nad nimi, ma charakter szczególny. Dotyczy bowiem ustosunkowania się do sposobu konstruowania przez młodych ludzi obrazu świata przez pryzmat własnego życia, na który składa się między innymi analiza minionych wydarzeń.

W celu lepszego zdiagnozowania opisywanych zjawisk odwołam się do pojęcia „przebiegu życia”, jest to kategoria, która odnosi się do „dynamiki życia jednostki, tj. do sekwencji i natężenia radzeń, doświadczeń czy przeżyć, towarzyszących realizacji różnych «karier» (...) i tworzących ostatecznie pewien typ biografii" (Rysz-Kowalczyk, Szatur-Jaworska 2004). W perspektywie przebiegu życia podkreśla się znaczenie czasu, kontekstu społecznego, kulturowego i historycznego, a także procesu, w trakcie którego zachodzą zmiany mające wpływ na kształtowanie się ludzkiego życia zarówno w kontekście rozwoju indywidualnego, jak i rodzinnego. Zmiana sytuacji życiowej poprzez przejęcie przez dziadków roli rodzica swoich wnuków zarówno w życiu jednych, jak i drugich staje się punktem przełomowym mającym istotne znaczenie w kontekście reinterpretacji przeszłości, teraźniejszości, ale również wpływającym na kształt przyszłości. Dzieje się tak dlatego, że choć sama sytuacja, w której znaleźli się wnukowie, ma podobny charakter, to jednak jest ona przeżywana w różny sposób. Z punktu widzenia podejmowanego zagadnienia istotny staje się sposób uświadamiania i postrzegania własnej sytuacji. Jak zauważa Alfred Schütz (1984: 142), człowiek w określony sposób przeżywa i interpretuje świat, nadając mu swoiste znaczenie w oparciu o zasoby wiedzy społecznej oraz własną biograficznie zdeterminowaną sytuację. To właśnie gromadzone doświadczenia przekładają się na znaczenia i interpretacje nadawane przez młode pokolenie wydarzeniom i sytuacjom mającym miejsce w ich życiu.

\section{Metodologia badań}

Opisywane w niniejszym artykule wyniki badań są częścią materiału zebranego przez autorkę w ramach pilotażowego projektu badawczego, dotyczącego formalnej i nieformalnej opieki dziadków nad wnukami. Badania realizowane w woje- 
wództwie podlaskim przeprowadzone zostały z wykorzystaniem podejścia jakościowego w okresie od listopada 2018 r. do maja 2019 r. Główną metodą zastosowaną w badaniach była metoda indywidualnych przypadków, a techniką - wywiad (Łobocki 2007). W badaniach doboru próby dokonano poprzez zastosowanie metody kuli śnieżnej polegającej na zaangażowaniu do badania uczestników wskazanych przez inne osoby badane. Wszyscy badani spełniali następujące kryteria: czasowe lub stałe wychowywanie przez dziadków, wiek 15 i więcej lat, zamieszkiwanie na terenie województwa podlaskiego. Do poniższych analiz spośród wszystkich przeprowadzonych wywiadów wybrane zostały wypowiedzi ośmiu pełnoletnich wnuków, w wieku pomiędzy 20. a 35. rokiem życia. Wybór podyktowany był wiekiem, w którym w chwili badania znajdowały się osoby badane, a mianowicie był to okres wczesnej dorosłości. Chere Campbell Coggins (1984) ten etap w życiu człowieka ukazuje jako okres, w którym „za kluczową w rozwoju człowieka dorosłego uważa on postawę wobec życia”. W tym czasie młodzi ludzie kształtują postawy wobec siebie, innych osób, życia i wiedzy oraz procesu jej zdobywania, a także rozwijają zdolność przyjmowania cudzej perspektywy. Wszystkie te czynniki mogą przekładać się na sposób postrzegania i opisywania zarówno sytuacji, w której znaleźli się wnukowie, jak i ich relacji z „dziadkami-rodzicami”. Ważnym w kontekście podejmowanych analiz jest fakt, że dziadkowie weszli w rolę rodziców, gdyż biologiczni rodzice byli alkoholikami, porzucili swoje dzieci, a także stosowali wobec nich przemoc. Miejsce zamieszkania narratorów było zróżnicowane, pochodzili z miejscowości, takich jak: Białystok, Sokółka, Siemiatycze, Bielsk Podlaski.

\section{Wyniki badań}

\section{„Nauka to do sukcesu klucz” - dziadkowie kowalami sukcesu edukacyjnego wnuków}

Edukacja przez wiele lat jest obecna w życiu człowieka, stanowiąc ważny element rozwoju jego osobowości. Dostępne w literaturze badania dotyczące osiągnięć edukacyjnych dzieci wychowywanych przez dziadków wskazują na wysokie ryzyko wystąpienia niepowodzeń w nauce. Wynika z nich, że wnuki napotykają trudności zarówno natury poznawczej, jak i emocjonalnej, są narażone na ryzyko wystąpienia drugoroczności oraz osiągają niskie wyniki w nauce (Gerard, Landry-Meyer, Roe 2006; Harris 2013). Przeprowadzone badania ujawniły, że wśród narratorów nie został wyeksponowany powyższy obraz ich własnej edukacji. Tego rodzaju doświadczeń nie dało się odnaleźć w relacjach interlokutorów, w których dominowały opowieści związane z pozytywnymi wspomnieniami, dotyczącymi nauki z dziadkami, która jawiła się wnukom jako dobra okazja do spędzania wspólnie czasu, a także łączenia obowiązku z zabawą. 
Bardzo lubiłam chyba pierwszy raz w życiu polubiłam matematykę bo $\mathrm{z}$ babcią to było takie przyjemne, bo się naprawdę śmiałam po prostu, bo ja robiłam jakieś zadanie i w tym czasie ona obok robiła swoje wyliczenia, u niej było inne u mnie inne, i takie i kto zrobił źle i zawsze wychodziło, że ja zrobiłam dobrze, ona zrobiła jakąs inną metodą i u niej cały rachunek poszedł. (Iza) ${ }^{1}$

I też, co po latach. Więc babcia właśnie ze mną siedziała. Co najbardziej właśnie wspominam, właśnie to, że siedziałyśmy razem, np. odrabiałyśmy te lekcje, że nie było tak, że musisz sama nie wiem coś tam zrobić... Tak, owszem było tak, że musiałam dojść sama i zbierałam, no przykładowo nie wiem, streszczenie do lektury, więc ja czytałam tą lekturę i pisałam jakieś tam na brudno streszczenie. $\mathrm{W}$ momencie, $\mathrm{w}$ którym przynosiłam to do babci, babcia to sprawdzała, poprawiała tam błędy ortograficzne, jak było ich dużo to było dyktando, tak (śmiech) ... więc miałam dyktando. Dbała o edukację. (Julia)

Przeprowadzone badania wskazują, że dziadkowie czuli się odpowiedzialni za edukację swoich wnuków, i nie tylko potrafili wymagać od dzieci, ale również od siebie samych.

Znaczy może nie wiem, jak babcia na co dzień była zaangażowana w mój proces edukacyjny ... (śmiech) to na pewno nie byłam zadowolona i miałam na górze swój własny pokój, który był dość duży, także jak już miałam powiedzmy dość to mówiłam, że sama pójdę sobie odrabiać lekcje i najwyżej później przyniosę do sprawdzenia, a w tym czasie komputer wszystkie odpowiedzi tyk, tyk, tyk o jak ładnie, ładnie, no i tak to wychodziło, ale zazwyczaj starałam się współpracować z babcią bo wiedziałam, że, że po coś ona to robi, dopiero po tych latach wiedziałam że chodzi o to żebym na przykład nie robiła byków jakiś ortograficznych. (Agnieszka)

Dla babci też było bardzo ciężko, siedziała, wałkowała i tak jak mówiła że ona potrafiła, ja jestem w szkole, a babcia siedzi w książkach ona nawet korepetytorkę wynajęła która przychodziła do babci i babcię uczyła żeby babcia mogła mnie nauczyć. (Monika)

To połączenie nauki, motywacji do działania oraz wspólnego spędzania czasu ma swoje odzwierciedlenie w postawach wnuków w okresie wczesnej dorosłości, gdyż, jak sami twierdzą, są osobami bardzo aktywnymi oraz dbającymi o własny rozwój. Pokazuje to, jak ważna jest postawa dorosłych w kontekście uczestniczenia $\mathrm{w}$ procesie edukacji dzieci i młodzieży. Uzasadnione zatem wydaje się prowadzenie badań mających na celu poszukiwanie czynników, które determinują sukces edukacyjny młodego pokolenia w kontekście oddziaływań wychowawczych „dziadków-rodziców".

\footnotetext{
1 Wszystkie imiona osób badanych występujące w tekście zostały zmienione.
} 


\title{
„Mądrość, której niczym nie da się zastąpić” - dziadkowie jako osoby mające dystans do różnych rzeczy pozwalający im widzieć, myśleć i mówić w „inny” sposób
}

Jednym z ważniejszych powodów, który zdaniem narratorów miał wpływ na odniesienie przez nich sukcesu $\mathrm{w}$ dorosłym życiu, było zaszczepienie im przez dziadków zdrowego poczucia własnej wartości.

\begin{abstract}
Nigdy od babci nie usłyszałam złego słowa, ona zawsze próbowała mnie podbudować, nigdy mi nie mówiła, że ja jestem jakąś złą osobą, czy porównywała mnie do mamy, nigdy, zawsze że ja jestem dobra, że zobaczysz że coś osiągniesz, nigdy nie płakałam przez babcię. Nawet jak nie zdałam matury to nie usłyszałam, że jestem jakimś tępakiem, który nie potrafi się nauczyć, tylko nie płacz zobaczysz, że zdasz w następnym roku, wszystko będzie dobrze, toż to tylko matura to nie koniec świata. (Monika)
\end{abstract}

Dziadkowie są też postrzegani przez wnuki jako osoby przekazujące historię rodziny, dziedzictwo i tradycje, a także jako gawędziarze snujący różnorodne opowieści.

Lubiłam z babcią posiedzieć bo to zawsze było oglądanie jakichś starszych filmów, babcia opowiadała jak się... bo ona się urodziła świeżo po wojnie także jeszcze pamięta te czasy PRL-u tak jak dalej, więc strasznie było... znaczy mi wtedy jako dziecko to było takie no nierealne bo teraz wszystko mamy na półkach, a tutaj babcia mówi, że nic nie było na półkach trzeba było za wszystko karteczkami płacić, jak ona to opowiadała jakieś tam jeszcze inne anegdotki ze swojego życia więc takie rodzinne opowieści.... Taki zwykły kontakt międzyludzki także po prostu dialog. (Agnieszka)

Często mi na przykład babcia opowiada jak było kiedyś, takie swoje wspomnienia z dzieciństwa, jakieś tam historie naszej rodziny, często przechodzimy na jakieś takie zwykłe tematy takie codzienne, takie że teraz jej siostra z bratem się kłócą, czy jakieś tam. (Joanna)

Lubimy ze sobą rozmawiać, ostatnio dowiaduję się dużo rzeczy z babci życia, jakie było kiedyś np. o wojnie czy coś takiego. Babcia opowiada o sobie, jak w tych czasach sobie radziła, kto był przy niej, opowiada jaka była moja mama kiedyś jak była mała. (Marta)

Zdaniem Alessandro Pronzato (2005: 150) „mądrość starych ludzi wprawia w zakłopotanie, bo nieuchronnie prowokuje dyskusję o znaczeniu, celach, ideałach, czyli o wszystkim tym, na czym naprawdę opiera się ludzka egzystencja i co nadaje jej wartość". Z wypowiedzi narratorów wynika, że dziadkowie zawsze byli takimi rodzicami, którzy z jednej strony potrafili nakierować, a z drugiej pozostawiali przestrzeń do podejmowania własnych decyzji. 
Zawsze to był mój wybór, jeżeli uważasz, że to jest dla ciebie ważne, że to jest coś co ci się podoba to idź i to rób. Nigdy babcia nie ingerowała w mój wybór nauki, zawsze to był mój wybór i zawsze rób dziecko tak żeby tobie było dobrze. (Julia)

Jak babcia się dowiadywała czegoś złego ze szkoły, zawsze była rozmowa, zawsze babcia rozmawiała próbowała wytłumaczyć, że przez takie zachowanie różne rzeczy mogą się stać, ale zawsze powtarzała, że wierzy we mnie i wie, że będę podejmował dobre decyzje. (Mateusz)

Wśród ról pełnionych przez dziadków w rodzinach wymienionych przez Vern L. Bengtsona (1985) znajduje się rola rodzinnego historyka, ukazująca dziadków jako osoby odpowiedzialne za podtrzymywanie ciągłości rodziny poprzez łączenie jej przeszłości z teraźniejszością, co przekłada się na poczucie zakorzenienia oraz ciągłości pokoleniowej. Relacje z dziadkami są bardzo cenione przez wnuki. Z perspektywy młodego pokolenia stają się oni inspiracją, a dzięki przekazywanej przez nich wiedzy są nauczycielami historii, a także przekazicielami rodzinnych tradycji.

Ciekawe w kontekście powyższych wypowiedzi wydaje się poszukiwanie czynników warunkujących przedstawianą przez wnuki postawę dziadków wobec ich wychowania. Biorąc pod uwagę fakt ponownego rodzicielstwa, można by było się spodziewać, że dziadkowie będą źli, niechętni i zmęczeni, a z wypowiedzi wnuków wynika, że potrafią w pełni zaspokajać ich potrzeby i wywiązywać się z przypisanych im ról. Warto jednak w tym miejscu zaznaczyć, że sytuacja jest przedstawiana jedynie z perspektywy wnuków, ważne by było zatem wzbogacenie opisywanego obrazu również z perspektywy dziadków. Czy w związku z powyższym ten pozytywny obraz znajdujący odzwierciedlenie w narracjach wynika ze wstydu, poczucia winy pojawiającego się u „dziadków-rodziców”, że ich dzieci nie sprawdziły się w roli rodziców, a oni (dziadkowie) są za to odpowiedzialni? Czy ich stosunek do wnuków jest rekompensatą za to, że sami popełnili błąd jako rodzice, a teraz próbują wynagrodzić swoim wnukom czas, kiedy byli zaniedbywani i odrzucani przez swoich biologicznych rodziców? A może wykorzystywane przez nich metody oddziaływań wychowawczych wynikają z życiowego doświadczenia oraz większej wrażliwości, refleksyjności i cierpliwości? W powyższych pytaniach pojawiły się obszary, które należałoby eksplorować w wywiadach z dziadkami, żeby uzyskać pełny obraz relacji pomiędzy wnukami a „dziadkami-rodzicami”.

\section{„Z dziadkami u boku życie jest piękne” - dziadkowie będący wparciem i towarzyszem w czasie wolnym}

Relacje międzypokoleniowe służą wzmacnianiu i wyrażaniu pozytywnych uczuć miłości, akceptacji i wzajemnego zrozumienia, „bycia razem”. Mają one również na celu łagodzenie pojawiających się napięć, jak również ułatwianie pojednania i dążenie do zgody. Pozytywne relacje z innymi, zdaniem Jerzego Halickiego (2010: 
29), to jeden $\mathrm{z}$ wymiarów pomyślnego starzenia się. Ważnymi komponentami w tym zakresie jest budowanie przyjaznych, nacechowanych zaufaniem kontaktów międzyludzkich.

Warto jednak podkreślić, że w omawianych przypadkach budowanie relacji międzypokoleniowych wiąże się ze zmianą sytuacji życiowej poprzez ponowne przyjęcie roli rodzica przez dziadków, tym razem wobec własnych wnuków. Wyzwaniem staje się już samo zaakceptowanie „starej-nowej” roli. W momencie przejęcia opieki nad wnukami w życiu dziadków następuje swego rodzaju zapętlenie, część doświadczeń (np. stan zdrowia, sprawność, dochody) ulega zmianom stosownie do wieku i przebiegu życia. W przypadku niektórych, np. parentyfikacja, która rozumiana jest jako odwrócenie ról w rodzinie, w następstwie którego dziadkowie pełnią rolę rodzica wobec własnych wnuków (Napora, Kozerska, Schneider 2014), następuje ich powtórzenie, choć niedokładne, bo sytuacja jest zmodyfikowana przez zmienione uwarunkowania. Z drugiej zaś strony w opisywanej sytuacji zarówno dziadkowie, jak i wnuki funkcjonują w płynnych rolach, będąc zarówno dziadkami i rodzicami, a także wnukami i dziećmi.

Mądrość dziadków pomaga wnukom odnaleźć się w nowej sytuacji. Dzięki podejmowanym przez dziadków działaniom dostrzegają oni zmiany, które następują w ich życiu, a które tłumaczyć można bardziej dojrzałymi postawami dziadków i ich racjonalnym podejściem do wielu spraw. Z wypowiedzi narratorów wynika, że dziadkowie byli często postrzegani jako osoby, z którymi młodzi ludzie mogli dzielić się problemami i obawami.

\begin{abstract}
Babcia nigdy mnie nie zawiodła, zawsze mogłam na nią liczyć, co by to nie było czy by się waliło czy nie, zawsze stawała w mojej obronie, nie pozwalała żeby ktoś mnie obrażała. Zawsze mogę na nią liczyć jakbym miała najmniejszy problem to ona potrafi mnie wysłuchać, zawsze mnie wspomoże, zawsze mnie wesprze. Jak mam trudny okres to codziennie mówi, że jestem silna, że dam radę, że sobie poradzę. Nigdy się też nie poddała, nawet jak miałam problemy, to mnie nie zostawiła, tylko wysłała mnie na leczenie, chodziła tam ze mną, nigdy nie było tak żeby wysłała mnie gdzieś samą, zawsze była przy mnie. Takie najtrudniejsze momenty to ja nawet nie musiałam jej prosić, ona po prostu sama czuła chyba że ja jej potrzebuję i zawsze była ze mną. (Monika)
\end{abstract}

Co ważne, w swoich wypowiedziach badani podkreślali, że czasami łatwiej było się zwierzyć dziadkom niż innym osobom, ze względu na bliskie relacje i więź, która ich ze sobą łączyła. Kluczową rolę odgrywało również poczucie, że sprawy wnuków zawsze były dla dziadków ważne.

Znaczy myślę, że wtedy właśnie trochę mi zastąpiła mamę, tak bardziej bo z mamą nawet obecnie nie mam takiego dobrego kontaktu, że nie wiem przyjdę, porozmawiam, zwierzę się, opowiem o problemach, a babci zawsze mogę o wszystkim powiedzieć. (Iza) 
Bliskie relacje dziadków z wnukami były możliwe również ze względu na realizację wspólnych zainteresowań. Wspólne spędzanie czasu wolnego było źródłem przyjemności i radości zarówno dla młodego, jak i starszego pokolenia.

Ale też bardzo dobrze wspominam wspólne wyjścia na ryneczek jak jeszcze to „Madro", nie „Madro" było tak, więc to było takie przyjemne bo za każdym razem jak szłyśmy to wracałyśmy obydwie z takimi torbami wielkimi. (Iza)

Ja myślę, że bardzo ważne było dla mnie właśnie to, że babcia bardzo dużo spędzała ze mną czasu tak jak już byłam w domu. Lubiłyśmy sobie wtedy pograć w karty, albo w jakąś planszówkę. Babcia też lubi rozwiązywać krzyżówki i wtedy ja często jej w tym pomagałam. (Agnieszka)

Wyniki badań wskazują na wyrażanie przez wnuki uznania dla umiejętności dziadków w zakresie zaspokajania ich potrzeb, zauważając znaczącą różnicę pomiędzy opieką ze strony dziadków i biologicznych rodziców. To dzięki dziadkom młodzi ludzie przekonali się, na czym polega głęboka rodzicielska miłość i na czym polega zaufanie do drugiego człowieka. Z wypowiedzi badanych wynika, że od momentu przejęcia nad nimi opieki przez dziadków wzrasta ich dobre samopoczucie. Wiąże się to zarówno z organizacją życia rodzinnego, dzięki której wzrasta poczucie bezpieczeństwa wnuków, oraz budowaniem więzi międzypokoleniowej, przede wszystkim poprzez ciągłe towarzyszenie wnukom w ich codziennym życiu.

\section{„Właściwe rzeczy we właściwym momencie” - „dziadkowie-rodzice” jako ważne osoby w wychowaniu wnuków}

Bliskie relacje $\mathrm{z}$ dziadkami są ważnym aspektem funkcjonowania wnuków i chociaż niewiele jest badań dotyczących wspomnianej relacji, to w dostępnych opracowaniach w swoich wypowiedziach dorośli biorący udział w badaniach często wspominają dziadków jako osoby znaczące w ich życiu (Longoria 2009; Kopera-Frye, Wiscott, Begovic 2003). Podkreśla się również znaczenie dziadków w wychowywaniu wnuków, wskazując fakt, że seniorzy mają im wiele do zaoferowania (Halicki 2006: 255-277).

W wypowiedziach badanych wnuków powtarzającym się aspektem były bliskie relacje z dziadkami, którzy zdaniem wnuków odegrali ważną rolę w ich wychowaniu.

Dzięki babci, która mówiła kim możemy zostać, dzięki naszej edukacji, dawała nam wskazówki co jeszcze możemy zrobić, w czym możemy działać. Zawsze było to argumentowanie, że możesz być kimś innym niż my jesteśmy, więc jakby stawiała nam cele do osiągnięcia, żeby nie stawać w miejscu tylko się rozwijać ciągle. Dzięki temu jesteśmy tu gdzie jesteśmy. (Mateusz) 
Ja zawsze babci mówię, że ty jesteś taką moją babcio - mamą, ty jesteś moją najlepszą przyjaciółką, że ja wszystko babci powiem, ja wiem że zawsze babcia mi doradzi, mimo że ja mogę się z tym nie zgadzać to wiem, że babcia ma rację. (Monika)

Babcia nauczyła mnie wszystkiego, więc to kim ja jestem to jest zasługa babci, moje codzienne życie to ja mówię, że to wszystko dzięki babci, bo ona nauczyła mnie kultury tak jak ja to mówię, więc tak naprawdę no wszystkiego od podstaw mnie nauczyła, więc ja mówię że to kim jestem to zasługa babci, więc ja chyba zawsze będę jej dziękować. (Monika)

To babcia wszystkiego mnie nauczyła, od małego, od czytania po jakieś tam poglądy na ludzi, na świat, jakieś tam wartości, no wszystkiego mnie nauczyła. (Joanna)

Gdyby nie babcia to nie wiadomo gdzie moglibyśmy być, moglibyśmy być nawet w jakiejś placówce. Zawdzięczamy dla niej wszystko, że jesteśmy, że też dała z siebie wszystko i starała się żebyśmy byli normalnymi dziećmi żebyśmy mieli wszystko co potrzeba dla każdego dziecka w tym wieku. (Mateusz)

Wszyscy narratorzy dzielili się przemyśleniami na temat luki wypełnionej przez dziadków, gdy ich rodzice nie byli w stanie zapewnić im odpowiedniej opieki. Większość podkreślała również, że to dziadkowie pomogli im pozostać na dobrej drodze i ustrzegli przed popełnianiem błędów. Szczególną rolę zdaniem narratorów starsi opiekunowie odegrali w zakresie ich edukacji, a także kształtowaniu systemu wartości.

Co więcej, należy zwrócić uwagę, że kontakty z wnukami mogą również być zależne od płci. Karolina Appelt (2007: 79-95) podkreśla, że w wychowaniu wnuków babcie zdecydowanie częściej koncentrują się na relacjach międzyludzkich, natomiast dziadkowie chętniej służą radą w zakresie tematów związanych z nauką, pracą czy też majsterkowaniem. Wypowiedzi wnuków wskazują, że podział zadań przypisanych do płci występuje również wśród ich dziadków.

Rodzina najważniejsza, ona zawsze powtarzała, że gdyby trzeba było to ona by zabiła za nas, zawsze mówiła, że wy jesteście dla mnie jak moje dzieci. Nigdy nie okazywała uczuć, znaczy nie okazywała może nie to że nie okazywała, nigdy nie mówiła o uczuciach, ale ja mówię że zawsze babciu liczą się czyny, i dla mnie najważniejsze jest to że mnie wzięłaś bo gdybyś nie kochała mnie to byś mnie nie wzięła ot tak po prostu. Ale nigdy nie było tak, że babcia przychodziła i mówiła, że o boże jak ja cię kocham, chyba że ja przychodziłam i mówiłam to babcia zawsze wtedy przytulała i mówiła że mnie kocha. (Julia)

Dziadek też wiem, że we mnie wierzy, tylko że dziadek o tym nie mówi. Dziadek jak robiłam remont $\mathrm{w}$ domu, to dziadek i garderobę mi zrobił i łóźka mi sam zrobił i biurko mi sam zrobił i okna mi na górze wymieniał, jak była potrzeba to on mi to robił, ale nigdy między mną a nim nie było takiej super relacji. (Monika) 
W wypowiedziach wnuków dominowała ogromna wdzięczność, wynikająca ze świadomości, że dziadkowie odegrali bardzo ważną rolę w ich życiu, przejmując nad nimi opiekę w trudnej sytuacji. Porównywanie obecnej sytuacji do warunków życia w rodzinie biologicznej staje się jednym z głównych punktów odniesienia do oceny relacji z „dziadkami-rodzicami”. W tym przypadku ważne stają się własne oczekiwania, wartości, potrzeby, które warunkują postrzeganie przez wnuki sytuacji, w której się znaleźli.

To że poświęciła całe swoje życie dla mnie, bo tak naprawdę pracowała, miała swoje życie, mogła wyjechać dalej za granicę, a jednak poświęciła wszystko żeby zostać tutaj. (Marta)

Jak zaczęłam dorastać to wtedy zrozumiałam, że żeby nie babcia to albo bym już nie żyła, albo bym wplątała się w towarzystwo, i nie wiem albo bym zaćpała, albo zapiła, czy coś takiego i tak jak mówię że tak jak teraz mam jedno dziecko, o które dbam to miałabym pięcioro o które bym nie dbała i powiedziałam babci, że to wszystko to jest jej zasługa. (Monika)

Wnuki biorące udział w badaniu w swoich wypowiedziach dają wyraz wyjątkowego spojrzenia na dziadków. Doświadczenie związane z wychowywaniem przez „dziadków-rodziców” przyczyniło się do zbudowania bliskiego, silnego związku z dziadkami. Powyższe wypowiedzi narratorów ukształtowane zostały poprzez kontekst dotyczący sytuacji życiowej, w której się znaleźli. Wiąże się on przede wszystkim z wcześniejszą sytuacją rodzinną wnuków, kiedy doświadczali niejednokrotnie obojętności ze strony rodziców biologicznych, a niekiedy stawali się osobami doznającymi z ich strony przemocy. Dopiero w momencie przejęcia opieki przez dziadków doświadczyli odmiennego traktowania. Dlatego też ich wdzięczność oraz lojalność wobec „dziadków-rodziców” jest odzwierciedleniem jasności co do roli, jaką dziadkowie pełnią w ich życiu od momentu przejścia z tradycyjnej roli dziadka do roli „dziadka-rodzica”.

\section{Podsumowanie}

Dziadkowie mogą odegrać kluczową rolę w życiu swoich wnuków, szczególnie wówczas, kiedy stają się jedynymi ich opiekunami. Przeprowadzone badania pilotażowe ukazały idealistyczny obraz „dziadków-rodziców” w oczach wychowywanych przez nich wnuków. Można przypuszczać, że ma to związek z wiekiem narratorów, w chwili badania bowiem wszyscy mieli co najmniej 20 lat lub więcej. Zatem mieli już za sobą burzliwy okres adolescencji, co nie tylko wynika z faz rozwojowych człowieka, ale co także potwierdzają relacje narratorów, a większa dojrzałość ich osobowości mogła przyczynić się do zachowania dystansu w ocenie doświadczeń z wcześniejszych lat, kiedy jako dzieci pozostawali pod opieką „dziadków-rodziców”. Spojrzenie na własną sytuację z perspektywy czasu pozwoliło na 
bardziej refleksyjne ustosunkowanie się do minionych wydarzeń. Większość wnuków biorących udział w badaniu wspominało trudności, które wiązały się z sytuacją mającą miejsce w rodzinie biologicznej, podkreślając jednocześnie, że dzięki zaangażowaniu i wsparciu ze strony dziadków udało im się pokonać przeciwności losu i dokonać wyboru dobrej drogi. W związku z powyższym w wypowiedziach wnuków dominowała ogromna wdzięczność, wynikająca ze świadomości, że dziadkowie odegrali bardzo ważną rolę w ich życiu. Doświadczenie związane z wychowywaniem przez „dziadków-rodziców” przyczyniło się do zbudowania bliskiego, silnego związku z dziadkami. Kolejny aspekt, który może mieć wpływ na obraz „dziadków-rodziców” w oczach wnuków, to oczekiwania związane z własnym życiem. Jeśli życie z dziadkami wydaje się lepsze od tego, które zdaniem wnuków mieliby w swoich rodzinach biologicznych, to można przewidywać, że ich ocena dotycząca opisywanych relacji również będzie bardziej pozytywna. Przeprowadzone badania pilotażowe wskazują na potrzebę pogłębienia eksploracji naukowych między innymi w zakresie poszukiwania odpowiedzi na pytanie dotyczące czynników warunkujących charakter relacji pomiędzy wnukami a „dziadkami-rodzicami”. Można by było wówczas uwzględnić większe zróżnicowanie wieku wnuków, a także perspektywę czasową uwzględniającą okres, który upłynął od momentu przejęcia opieki przez dziadków. Kluczowy mógłby się okazać również wiek dziadków w momencie przejmowania opieki nad wnukami. Wiedza dotycząca czynników mających wpływ na relacje tworzące się pomiędzy osobami z dwóch opisywanych pokoleń mogłaby zostać wykorzystana przez praktyków, którzy pracują z takimi rodzinami.

\section{Bibliografia}

AIHW (2013) Child Protection Australia 2011-12, Canberra, Australian Institute of Health and Welfare.

Appelt K. (2007) Współcześni dziadkowie i ich znaczenie dla rozwoju wnuków w: A. I. Brzezińska, K. Ober-Łopatka, R. Stec, K. Ziółkowska (red.), Szanse rozwoju w okresie późnej dorosłości, Poznań, Wydawnictwo Fundacji Humaniora.

Bengtson V. L. (1985) Diversity and symbolism in grandparental roles w: Grantparenthood, V. L. Bengtson \& J. F. Robertson (red.), Beverly Hills, CA: Sage.

Boetto H. (2010) Kinship care: a review of issues, „Family Matters”, 85, s. 60-67.

Borowik J. (2016) Nietradycyjna rola dziadków $w$ rodzinie migracyjnej - uwarunkowania i konsekwencje w: Opieka nad dziećmi i starszymi rodzicami w rodzinach migrujacych kobiet, Z. Kawczyńska-Butrym, E. Czapka (red.), Lublin, Wydawnictwo POLIHYMNIA. 
Coggins C. C. (1980) Individual Growth Through Community Problem Solving w: R. O. Boyd, J. W. Apps i in., Redefining the Discipline of Adult Education, San Francisco, JosseyBass.

Cox C. B. (2000) To grandmother's house we go and stay: Perspectives on custodial grandparents, New York, NY: Springer.

Dubas E. (2009) Etapy dorosłości i proces kształcenia w: Dorosły w procesie kształcenia, A. Fabiś, B. Cyboran (red.), Bielsko-Biała-Zakopane, Wyższa Szkoła Administracji.

Fitzpatrick M. (2004) Grandparents Raising Grandchildren, Melbourne, Council on the Ageing.

Gerard J. M., Landry-Meyer L., Roe J. G. (2006) Grandparents raising grandchildren: The role of social support in coping with caregiving challenges, „International Journal of Aging and Human Development", 62, s. 359-383.

Giddens A. (2012) Socjologia, Warszawa, Wydawnictwo Naukowe PWN.

Grandparents Plus (2006) Forgotten Families, London, Grandparents Plus and Adfam.

Halicki J. (2010) Obrazy starości. Rysowane przeżyciami seniorów, Białystok, Wydawnictwo Uniwersytetu w Białymstoku.

Halicki J. (2006) Społeczne teorie starzenia się w: Zostawić ślad na Ziemi, J. Halicki, M. Halicka (red.), Białystok, Wydawnictwo Uniwersytetu w Białymstoku.

Harris D. M. (2013) Grandma's hands rocked the cradle, „Children and Youth Services Review", 35, s. 2072-2079.

Kopera-Frye K., Wiscott R. C., Begovic A. (2003) Lessons Learned from Custodial Grandparents Involved in a Community Support Group w: Working with Custodial Grandparents, B. Hayslip, J. H. Patrick (red.), New York, Springer Publishing.

Longoria R. A. (2009) Grandparents raising grandchildren: perceived neighborhood risk as a predictor of emotional well-being, ,Journal of Human Behavior in the Social Environment", 19, s. 483-511.

Łobocki M. (2007) Metody i techniki badań pedagogicznych, Kraków, Oficyna Wydawnicza „Impuls”.

Mason J., Falloon J., Gibbons L., Spence N., Scott E. (2002) Understanding kinship care, Haymarket, Association of Children's Welfare Agencies.

Napora E., Kozerska A., Schneider A. M. (2014) Parentyfikacja dziadków czynnikiem resilience w funkcjonowaniu rodziny samotnej matki - przegląd badań, „Kultura i Edukacja”, nr 1 (101), s. 51-71. 
Napora E., Kozerska A., Miszczak E. (2014) Wsparcie dziadków w rodzinie o różnej strukturze a jakość życia młodzieży, „Acta Humanica”, nr 2, s. 161-170.

Ochiltree G. (2006) The Changing Role of Grandparents, Melbourne, Australian Institute of Family Studies.

Pronzato A. (2005) Starość czasem nadziei, Kraków, Wydawnictwo Salvator.

Rysz-Kowalczyk B., Szatur-Jaworska B. (2004) Polityka społeczna wobec cyklu życia. Faza starości w: Nasze starzejące się społeczeństwo. Nadzieje i zagrożenia, J. T. Kowaleski, P. Szukalski (red.), Łódź, Wydawnictwo Uniwersytetu Łódzkiego.

Schütz A. (1984) Potoczna i naukowa interpretacja ludzkiego działania, tłum. D. Lachowska w: Kryzys i schizma. Antyscjentystyczne tendencje w socjologii współczesnej, E. Mokrzycki (red.), Warszawa, Państwowy Instytut Wydawniczy.

\section{Źródła internetowe}

Arpino B., Pronzato C. D., Tavares L. P. (2012) Mother's Labour Market Participation: Do Granparents Make It Easier?, http://ftp.iza.org/dp7065.pdf [dostęp: 15.11.2019].

Selwyn J. T., Nandy S. (2012) Sibling kinship carers in England: evidence from the 2001 UK Population Census, "Children and Youth Services Review”, 34, s. 194-199, https://www.sciencedirect.com/science/article/pii/S019074091100363X?via\%3Dihub [dostęp: 18.11.2019].

Simmons T. \& Dye J. L. (2003) Grandparents Living with Grandchildren: 2000. (Census Bureau Publication No.C2KBR-31). Washington, U.S. Census Bureau, https://www.census.gov/prod/2003pubs/c2kbr-31.pdf [dostęp: 18.11.2019]. 